\title{
A Look at Wildlife Management in India
}

\author{
Malcolm Coe
}

The author, who has studied and advised on wildlife management and park problems in Africa, describes some of the differences he noted in India. He looks at the effects of management in Kanha National Park, where the bans on stock grazing and tree felling and the removal of villages have benefited two endangered species-tiger and barasingha-and shows the need for more study and understanding of the large herbivores in order to manage the park successfully.

In September 1975 and January 1977 I was fortunate enough to be able to visit India to lecture in Indian universities and to discuss wildlife research and training with the staffs of the national parks. Having spent over twenty years working with wildlife in Africa it was especially interesting to see a flora and fauna that were in some ways familiar and in others totally different. In the south much of the apparently semi-arid landscape near the city of Madurai bore a close resemblance, even at the plant genus level, to African scrub savannas, while the deserts of the west, in Rajasthan, could well have been in northern Kenya. In the north, however, where the great sal Shorea robusta forests straddle the continent, one enters a new and strange land of vast, seemingly endless deciduous forest. The broad green leaves of these Dipterocarpaceae are characteristic of a family that dominates the forests of these parts of India through to South-east Asia.

When we talk of national parks in the Old World tropics most of us think of Africa. But in fact India has 152 gazetted or proposed sanctuaries, 15 national parks and nine bird sanctuaries, 176 in all, as well as many smaller areas. With their varying degrees of protection and management they comprise about $64,000 \mathrm{sq} \mathrm{km}$, or about three times the area of the Tsavo National Park in Kenya. Moreover, they occur in virtually all India's main climatic/vegetation zones, although perhaps not surprisingly many of the bigger sanctuaries and parks are in former forest reserves. Indeed when we recognise this fact we realise the importance and significance of the Indian Government's action in giving full national park status to new reserves and also enlarging them. In Africa most of the bigger national parks were gazetted in areas where agricultural potential is poor or the human population is low. But in India, not only is there great pressure on the land for agriculture, but where these areas support dense forest the timber revenue lost as a result of their changed status is far greater per unit area than the loss in virtually any area of similar status in Africa. The ecological problems when a national park is gazetted are incredibly complex, for in both forest and mixed forest and grassland these regions have in the past been exploited for timber extraction (including bamboo), cattle grazing, firewood and even for green leaves, which provide a neat source of biodegradable plates for the dining table.

During my two visits to India I was able to visit three national parks, Kanha (934 sq $\mathrm{km}$ ), Palamau (345 sq $\mathrm{km}$ ), and Corbett (525 sq km), and Ranthambor (392 sq km), all administered under Project Tiger, which is jointly funded by the Indian Government and the World Wildlife Fund. I also spent 


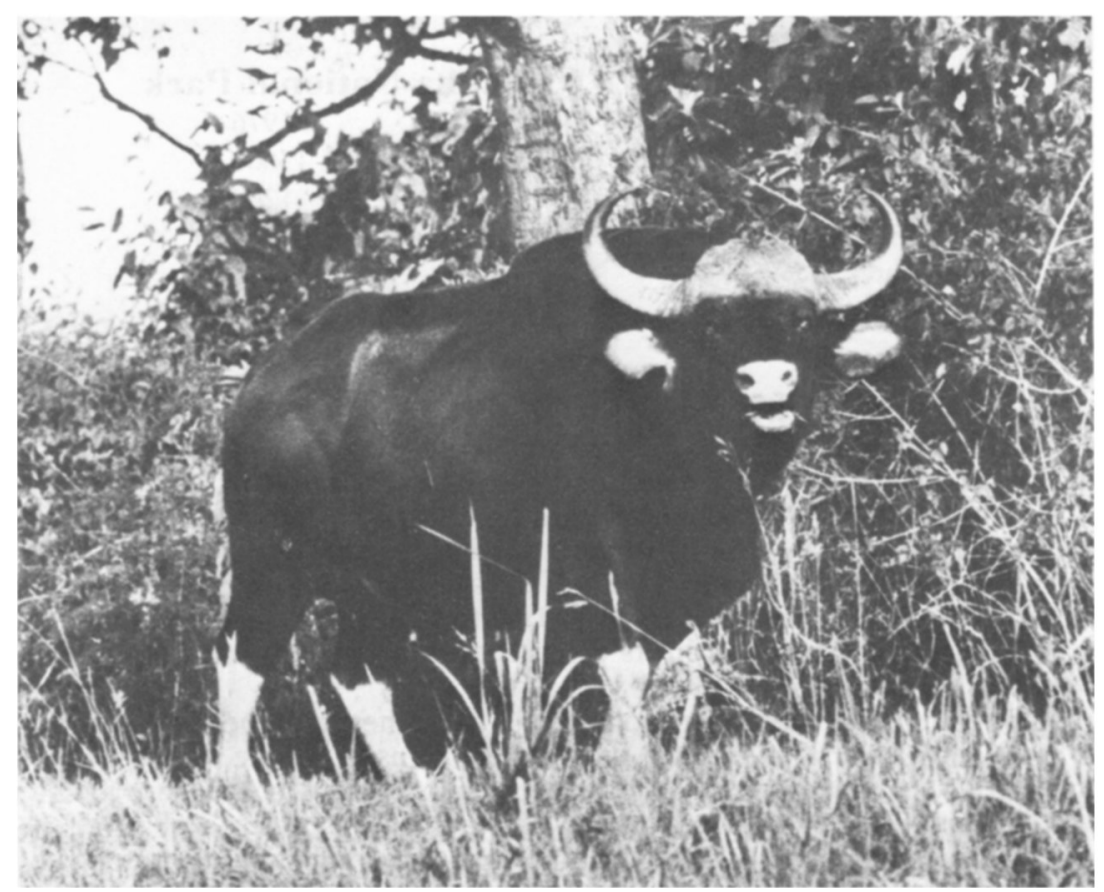

GAUR E.P.Gee

some time in Periyar Wildlife Sanctuary (777 sq km) in Kerala, and the Dudhwa National Park $(500 \mathrm{sq} \mathrm{km})$ in Uttar Pradesh, close to the Nepal border. All have much to offer the discriminating visitor. It is true, of course, that in these primarily forested areas visibility is not as good or as easy as in the open savannas of Africa, but in most parks track verges are kept open by cutting, allowing the patient visitor to view a wide variety of game with a green backdrop of often equal beauty. There is generally comfortable and reasonably priced accommodation with the opportunity to sample the delights of Indian cuisine. Road transport between one area and another is often slow, but for the visitor who tries to understand the context in which wildlife conservation must be viewed, the whole scene is enhanced by the pace at which one is so often forced to travel, enabling him to see, smell and feel the atmosphere of a new and totally different environment. In many national parks there is often an opportunity to view the wildlife at night, when the huge gaur Bos gaurus may approach to within a few feet of the jeep. For most visitors, however, the highlight will be the slow lumbering pace of riding on an elephant, when even the insects in the trees are close enough to be viewed at leisure.

A predominant feature of the large herbivorous mammals in India is the great variety of deer species, which are noticeably absent from Africa. Nevertheless, a comparison of habitats in India and Africa forces one to realise that there are many similarities between these taxonomically unrelated faunas, so much so that we might refer to them as 'ecological analogues'. The very common chital or axis deer $A$ xis axis, which live in small herds mainly along the forest/grassland ecotone, behave in a similar manner to impala Aepyceros melampus, while in the denser forests and scrub jungles the sambar Cervus unicolor is reminiscent of the African bushbuck family. The visitor would be unlucky not to see these species in quite a short space of time, together with the regal barasingha Cervus d. duvauceli in Dudhwa or even the rare dry-ground 
Table 1

$\begin{array}{lr} & 1973 \\ \text { Chital } & 9000 \\ \text { Sambar } & 1050 \\ \text { Barasingha } & 118 \\ \text { Gaur } & 550 \\ \text { Wild pig } & 1064 \\ & \text { Panwar, } 1977\end{array}$

Kanha National Park

1976

13600

1200

215

600

1874

C.d.branderi on the open grasslands of Kanha. The more watchful eye may spot the muntjac Muntiacus muntjak, a deer that bears a striking resemblance in its shape and behaviour to the forest duikers of Africa, while in the tall open grasslands of the Corbett National Park the shy hog deer Axis porcinus, in many ways reminiscent of the African common duiker Sylvicapra grimmia, is not uncommonly associated with herds of chital. The close resemblance of the nilgai or blue bull Boselaphus tragocamelus to the African eland Taurotragus oryx is remarkable, not only in its colour and morphology but also its social behaviour.

It is of course the larger deer species that, together with the gaur, comprise the most important items of the tiger's diet. Thus in all the wide variety of habitat types associated with Project Tiger, management policies are directed towards maximising the productivity of tiger prey species. Such policies, however, are often more difficult than they appear, for they presuppose that we know what the carrying capacity is for each of the prey species, whereas in fact, without detailed studies of the ecology and population dynamics of each of them, we are left with little alternative but to try out a management technique and observe its effects.

Both Eisenberg and McKayl and Eisenberg and Seidensticker ${ }^{2}$ have pointed out that the biomass of large herbivores in India decreases as the degree of forest cover increases and grassland is reduced. This phenomenon is similar to that observed in Africa as we pass from the grasslands of East Africa to the dense forests of West Africa. To a large degree these biomass changes may be related to rainfall, for increased precipitation supports increasingly woody vegetation of which a decreasing percentage of the annual production is actually available as food for large herbivores.

$W_{1 \text { ith }}$ the establishment of national parks in India many authorities have excluded grazing from the core areas, prevented the extraction of timber, and also moved villages beyond the park boundaries. As a result wild herbivore numbers have increased, especially in those grazing or mixed-feeding species that can take advantage of the grassland areas that mark the old village sites. It is interesting to examine the changes in herbivore numbers that have resulted from the exclusion of human activity. Data from the Kanha National Park-see Table 1 -show that chital have increased by 51 per cent, barasingha by 81 per cent, sambar by only 14 per cent and gaur by only 9 per cent. These changes can be closely related to their feeding habits. Schaller ${ }^{6}$ showed that both chital and barasingha are primarily grazers, while sambar and gaur are mixed feeders with a wide preference for the different forest types. Thus, as might have been expected, the removal of human activity from the grasslands (maidans) released large quantities of grass for these two predominant grazers, while essentially forest-dwelling species were less affected. Indeed, for the latter, the prevention of fire and grazing by domestic animals under stands of open deciduous 'sal' forest may well have made some food types less available.

Figure la illustrates diagrammatically the two predominant land types of 


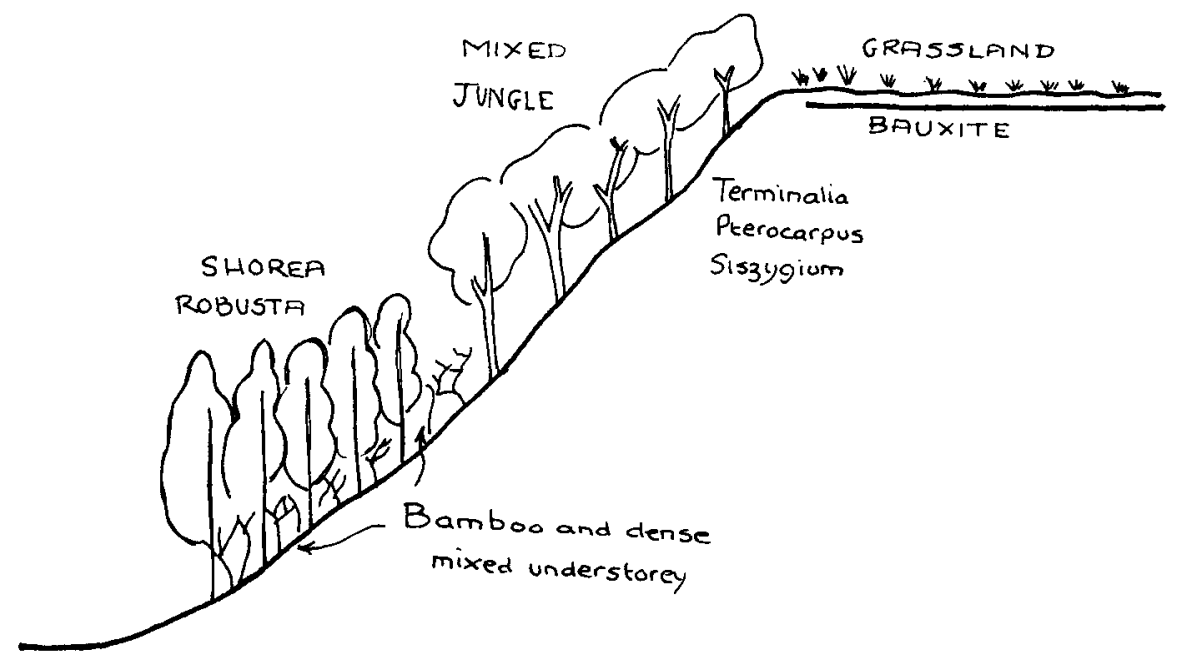

Fig. 1a Main habitat types in Kanha: a steep hill slopes

Kanha and their associated vegetation: on steep slopes sal forest with a dense understory clothes the lower slopes, a mixed jungle occurs on the upper slopes and the hills are capped by grassland underlain by bauxite. On the less elevated areas extensive open sal forest with little understory predominates, while on the flat lower areas the derived grasslands (maidans) and forest edge are the preferred habitats of chital and barasingha (Fig. lb). Of special interest on the maidans is the slow intrusion of fire and frost-resistant trees, Butea monosperma and Lagerstroemia parviflora, which rapidly colonise deserted agricultural land. Numerous frost hollows in these regions are characterised by short grass. The need for regular management by cutting and fire becomes apparent when we see the important relationship between these grasslands and the increase in the herbivores.

The increased grazing at Kanha has not only provided tiger prey, but has also been responsible for the preservation of the rare 'hard ground' barasingha. A population of these splendid deer numbering 3000 in 1938 was by 1970 reduced to 66 , due to poaching and the reduction of their preferred grassland. By 1976 numbers had gone up to 215 , an average increase of 38 per cent per annum. ${ }^{3}$ The fact that they have been able to sustain this increase in the face of tiger predation indicates that this important management feature has benefited two endangered species.

In his studies of the large mammals in Kanha between December 1963 and January 1965 , Schaller ${ }^{6}$ attempted to estimate the biomass of large herbivores. If we recalculate his data (expressed in $\mathrm{lb}$ per sq. mile) we observe that an area

Fig. 1b Open derived grasslands (maidans) bordered by extensive sal forest

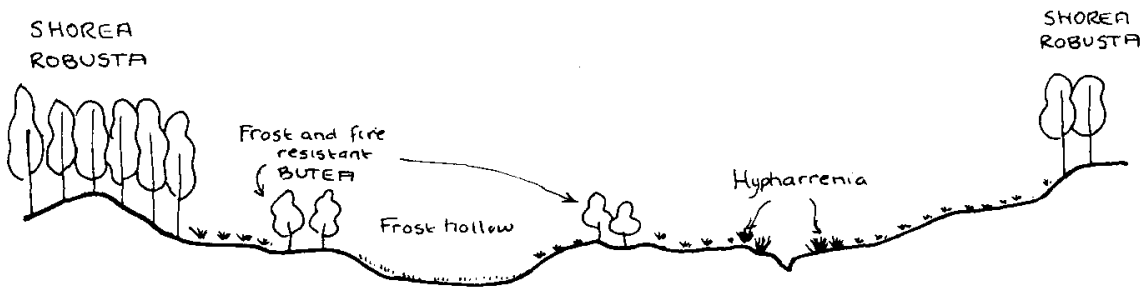




$\begin{array}{lccccr}\begin{array}{c}\text { Table 2 } \\ \text { Species }\end{array} & \begin{array}{c}\text { Average } \\ \text { Weight } \\ \mathrm{kg}\end{array} & \begin{array}{c}\mathbf{1 9 6 4}^{6} \\ \text { Density } \\ \text { sq km }\end{array} & \begin{array}{c}\text { Biomass } \\ \text { kg per } \\ \text { sq km }\end{array} & \begin{array}{c}\mathbf{1 9 7 6}^{5} \\ \text { Density } \\ \text { sq km }\end{array} & \begin{array}{c}\text { Biomass } \\ \text { kg per } \\ \text { sq km }\end{array} \\ \text { Gaur } & 582 & 0.6 & 349 & 0.6 & 349 \\ \text { Sambar } & 148 & 0.7 & 103 & 1.1 & 162 \\ \text { Chital } & 45 & 3.0 & 135 & 14.2 & 639 \\ \text { Barasingha } & 159 & 0.2 & 32 & 0.2 & 31 \\ \text { Muntjac } & 18 & 0.4 & 7 & 0.4 & 7 \\ \text { Blackbuck } & 23 & 0.04 & 1 & 0.1 & 2 \\ \text { Chousinga } & 18 & 0.3 & 5 & 0.05 & 1 \\ \text { Nilgai } & 182 & 0.1 & 18 & 0.03 & 5 \\ \text { Wild pig } & 27 & 0.5 & 13 & 2.0 & 54 \\ \text { TOTAL } & & & 668 & & 1250\end{array}$

of $315 \mathrm{sq} \mathrm{km}$ sustained a standing crop biomass of $660 \mathrm{~kg}$ per sq $\mathrm{km}$ of wildlife and $1806 \mathrm{~kg}$ per sq km of domestic stock (including elephant), a total of $2466 \mathrm{~kg}$ per $s q \mathrm{~km}$. The standing crop biomass on his study area of $52 \mathrm{sq} \mathrm{km}$ carried up to $2284 \mathrm{~kg}$ per sq $\mathrm{km}$ (not 3693 as stated by Schaller). Schaller concluded that after cattle and buffalo were excluded from the forest the Kanha Park was capable of carrying a wild ungulate biomass similar to that found on his study area (i.e. $2284 \mathrm{~kg}$ per sq $\mathrm{km}$ ).

Many changes have taken place in Kanha since then, including the dramatic increase in the numbers of grazing species. If we calculate the present biomass from numbers recorded in 1976 by Panwar, ${ }^{5}$ using the same average weights as Schaller, we find that the total core area $(934 \mathrm{sq} \mathrm{km})$ now carries up to $1250 \mathrm{~kg}$ per sq $\mathrm{km}$ (Table 2), while if we consider that these figures should be spread over the buffer zone as well $(273 \mathrm{sq} \mathrm{km})$ this biomass is reduced to $969 \mathrm{~kg}$ per sq $\mathrm{km}$. This figure is considerably below that predicted by Schaller. ${ }^{6}$ If, however, we examine the percentage of the total biomass contributed by different herbivore species we see that the gaur has fallen from 50 to 27 per cent, while the chital have risen from 19 to 51 per cent, which again demonstrates the importance of the grass made available to the grazing species. The barasingha have increased from 75 to 215 but their biomass has remained the same ( $31 \mathrm{~kg}$ per $s q \mathrm{~km}$ ), suggesting that they have merely extended their range over a wider area of suitable grassland.

A heterogeneous environment like Kanha poses two rather different management problems. Forest habitats favour mixed feeders, and much of the ground vegetation may favour domestic grazing animals coupled with fire to maintain it in a state suitable for wild herbivores. In grasslands, on the other hand, while the exclusion of domestic stock and agriculture may well increase the food levels of wild herbivores, the intrusion of fire-resistant plants in the absence of intensive stock grazing means that artificial means have to be used to maintain these areas in an early successional stage. The fact that the wild herbivore biomass has not risen as high as Schaller predicted can probably be accounted for by the fact that the observed increase of 43 per cent has been almost entirely in medium-sized deer species whose annual production must be considerably higher than large bovids such as the gaur. Additionally, Schaller's study area was probably a more seasonal feeding area than he recognised under 
the climatic conditions prevailing at the time.

Thus we see that the exclusion of man from the many habitat types available to game species in India raises different management problems from those in most African national parks. The need for extensive studies of Indian large herbivores in relation to their habitat requirements and food resources, both in the presence and absence of human husbandry, is self-evident.

\section{Abstract}

India has 176 gazetted or proposed sanctuaries and national parks. Since so many of these areas occur in deciduous forest the revenue lost both nationally and locally is often far greater than in the semi-arid regions of Africa when similar conservation legislation is enacted. The Kanha National Park has shown interesting increases in the large herbivore population since felling and grazing were stopped, although some of these activities are continued as a management practice, especially on grasslands.

\section{Acknowledgments}

I should like to express my sincere thanks to the British Council for their great kindness in arranging for the opportunity to visit the National Parks of India. In India I must acknowledge the assistance of Drs Ashoke Chandra and Julian Schweitzer, and Mr S. M. Ali, who accompanied me on some of my travels. In Kanha the Director, H. S. Panwar, gave up much of his valuable time to discuss management problems with me. To the people of India who extended the hand of friendship wherever I went I shall be eternally grateful.

\section{References}

1. EISENBERG, J. F. and McKAY, G. M. 1974. Comparison of ungulate adaptations in the New World and Old World tropical forests with special reference to Ceylon and the rain forests of Central America. In: The Behaviour of Ungulates and its Relation to Management, ed. by V. Geist and F. Walther. IUCN Publication, New Ser. No. 24: 585-602.

2. EISENBERG, J. F. and SEIDENSTICKER, J. 1976. Ungulates in Southern Asia: a consideration of biomass estimates for selected habitats. Biol.Conserv. 10:293-308.

3. PANWAR, H. S. 1976. Success with the Branderi Barasingha (Cervus duvauceli branderi) in Kanha National Park. Mimeographed report: 1-20.

4. PANWAR, H. A. 1977. Project Tiger, Kanha Tiger Reserve. Position paperJanuary 1977. Mimeographed report: pp.1-34.

5. PANWAR, H. S. 1977. Pers. comm.

6. SCHALLER, G. 1967. The deer and the tiger. Univ. of Chicago Press.

Dr Malcolm Coe, Animal Ecology Research Group, Department of Zoology, South Parks Road, Oxford OX1 3PS.

\section{Persian Fallow Deer}

Four female Persian fallow deer Dama dama mesopotamica have been presented to Israel and have now joined the two males, already held in Hai-Bar Carmel-a 2000-acre fenced area on Mount Carmel, where they have a 40 -acre enclosure. The latest information about these deer in the wild in Iran is that numbers have increased considerably in the Dasht-e-Naz Wildlife Refuge in north-central Iran and now total 50-55 animals. Also a male and 2 females have been flown to a 2600 -ha island in the north-west and appear to be adapting well. It is hoped to build up a new population there. In south-west Iran two populations in two wildlife refuges are estimated to number between 40 to 65 animals, but the outlook for them is less hopeful. 